\title{
Social Justice, Class and Race in Education in England: Competing Perspectives
}

\author{
Abstract \\ 'Narrowing the gap' and addressing low educational achievement of specific social \\ class and ethnic groups has long been an expressed government concern. This paper \\ considers the links between poverty, ethnicity and gender and school attainment and \\ the inter-relations of these factors using national data sets and other quantitative data. \\ The limitations of single theme analyses and their potentially misleading implications \\ are explored. Related to this, the failures of social and educational policies to bring \\ about greater equality are examined. \\ Competing perspectives on low attainment and their positions are critiqued. The paper \\ argues that ethnic and class discrimination stems from the same structural \\ arrangements contrived for the advantage of more affluent sectors of society. \\ Theoretical development is needed to bring together class, race and other \\ discriminatory features and construct more sophisticated causal analyses which relate \\ to the web of economic, status and power regimes and the negative processes of \\ 'racialisation'.
}

Key words: social class; ethnicity; gender; educational attainment; social justice 


\section{Introduction}

Inequality in school outcomes has long been an educational policy issue. Within the broad area of social justice in education, the paper begins with a consideration of poverty and its relationship to educational attainment and other life chance dimensions. The following sub-section gives an account of ethnic groups and their differential attainment, drawing on explanations offered by British and American race theorists (Gillborn, 2005, 2008, 2015; Ladson-Billings, 2009). The third sub-section looks at gender and attainment, noting particularly the unchanging female advantage at every level.

The following two sections examine interpretations of the links between poverty and education, and then theorising around race, racism and ethnicity and attainment in England, including some reference to the USA with due regard to the different sociohistorical and contemporary contexts. A section is then devoted to examining how race and class theorists may reasonably pursue research, critique policy and promote equality practices and institutional arrangements in ways which are mutually supportive.

It is argued that, in the England context, poverty as a powerful underlying force is eclipsed in policy considerations about low educational attainment by other themes: a prominent approach has been under the heading of 'school improvement' (Harris, 2009; Woods and Brighouse, 2013). Other high profile publications concern 'race', much of which is written under the umbrella of critical race theory (CRT) (Gillborn, 2006b; Hylton et. al. 2007). Both perspectives, as currently configured, struggle to offer social and/or political remedies for the variety of educational attainment levels of different ethnic groups or low attainment associated with social class in England. A promising structuralist position (Apple, 2015; Cole, 2017; Darder and Torres, 2004; 
Dorling and Tomlinson, 2016; Reay, 2017) would draw attention to power relations and the political mechanisms which create and sustain poverty, discrimination and inequalities. Potentially, such consolidated analyses encompassing allocation of funding and class-based decision-making in education would provide a basis for more sustained and effective action than we have seen hitherto.

The paper draws on two sources of quantitative data: publicly available First Statistical Releases from the Department for Education (DfE) which give attainment results for the year for all key stages (2017 publications used); and two longitudinal national datasets of around 500,000 pupils reaching 16 in 2012 and 2015 through requested access to the DfE's National Pupil Database ${ }^{1}$ (NPD). The work of Strand (2008, 2011, 2014a) provides key reference points in considering quantitative data and the findings related to the relative power of the demographic factors statistically related to attainment.

\section{Social justice and the education offer}

Social justice in relation to education is a unique case where a young person's future can be hugely influenced, if not determined, by factors such as socio-economic background, race and gender over which they have no control, for which they can bear no responsibility but contribute, on average, significantly and measurably, to effects which last through life. The sub-sections here examine poverty, ethnicity and gender and their enduring, relatively stable association with measures of achievement. It is important to grasp the various dimensions of inequality, how they combine, how the same range of factors impact on education and other areas of life and the ineffective policy responses, which arise from blinkered perspectives on the attribution of causes.

\section{Poverty and educational attainment}


In England, poverty/education/childhood researchers have been active for at least two centuries. In recent times, Wedge and Prosser (1973), Tomlinson (2001), Smythe and Wrigley (2013) and Reay (2017) have made the case for the impact of deprivation on development, and the Child Poverty Action Group (Tucker, 2016) and the Joseph Rowntree Foundation (Christensen, 2009) have maintained a continuous flow of campaigning on redistribution and welfare increases.

Table 1 sets out an analysis of attainment at three key stages for two complete national cohorts of half a million pupils acquired from the National Pupil Database (DfE, 2015). These data are complete sets provided to a template set by the researcher anonymised at the individual level. These sets were provided with demographic data and attainment measures over the period of their compulsory schooling. Some attainment data are missing for KS1 and, to a lesser extent, from $\mathrm{KS} 2^{2}$, but analyses using only the 450,000 with complete attainment data makes little difference to the percentages given in Tables 1 or 3 .

Table 1: Income Deprivation Affecting Children Index (IDACI) deciles and percentages reaching 'expected levels' of attainment in England in 2012 and 2015

\begin{tabular}{|c|c|c|c|c|c|c|}
\hline \multirow[b]{2}{*}{$\begin{array}{l}\text { IDACI } \\
\text { decile }\end{array}$} & \multicolumn{3}{|c|}{ Cohort reaching 16 in $\mathbf{2 0 1 2}$} & \multicolumn{3}{|c|}{ Cohort reaching 16 in $\mathbf{2 0 1 5}$} \\
\hline & $\begin{array}{l}\text { KS } 1 \\
\text { Level } 2 \\
\text { reading, } \\
\text { writing } \\
\text { \& maths } \\
\quad \% \\
\end{array}$ & $\begin{array}{l}\text { KS } 2 \\
\text { Level } 4 \\
\text { reading, } \\
\text { writing \& } \\
\text { maths } \\
\quad \% \\
\end{array}$ & $\begin{array}{c}\text { KS } 4 \\
5 A^{*}-C \\
\text { GCSEs } \\
\text { including } \\
\text { Eng \& maths } \\
\quad \% \\
\end{array}$ & $\begin{array}{c}\text { KS } 1 \\
\text { Level } 2 \\
\text { reading, } \\
\text { writing } \\
\text { \& maths } \\
\quad \% \\
\end{array}$ & $\begin{array}{l}\text { KS } 2 \\
\text { Level } 4 \\
\text { reading, } \\
\text { writing } \\
\text { \& maths } \\
\quad \% \\
\end{array}$ & $\begin{array}{c}\text { KS } 4 \\
5 A^{*}-C \\
\text { GCSEs } \\
\text { including } \\
\text { Eng \& maths } \\
\quad \% \\
\end{array}$ \\
\hline Poorest $10 \%$ & 66.7 & 57.0 & 34.9 & 73.4 & 63.3 & 39.2 \\
\hline $11-20 \%$ & 71.1 & 59.7 & 37.6 & 76.3 & 65.0 & 40.9 \\
\hline $21-30 \%$ & 74.6 & 63.9 & 42.0 & 79.3 & 68.0 & 44.7 \\
\hline $31-40 \%$ & 77.4 & 66.9 & 45.5 & 81.3 & 70.6 & 48.6 \\
\hline $41-50 \%$ & 80.2 & 70.0 & 50.2 & 83.7 & 73.9 & 53.0 \\
\hline $51-60 \%$ & 82.5 & 74.0 & 55.3 & 85.8 & 76.6 & 57.7 \\
\hline $61-70 \%$ & 84.7 & 76.5 & 59.7 & 87.2 & 79.0 & 61.6 \\
\hline $71-80 \%$ & 86.1 & 78.8 & 63.6 & 88.6 & 81.2 & 65.4 \\
\hline $81-90 \%$ & 87.9 & 81.3 & 67.4 & 89.8 & 83.5 & 68.8 \\
\hline Most affluent $10 \%$ & 90.1 & 84.6 & 73.0 & 91.6 & 86.4 & 74.6 \\
\hline \multicolumn{7}{|c|}{ FREE SCHOOL MEALS } \\
\hline FSM & 64.5 & 53.0 & 29.4 & 72.1 & 59.2 & 32.8 \\
\hline
\end{tabular}




\begin{tabular}{lccll|rrc} 
Non-FSM & & 84.5 & 76.2 & 59.0 & 87.5 & 79.9 & 63.8 \\
\hline \multirow{2}{*}{ Gender } & Girls & 84.2 & 71.8 & 61.5 & 87.4 & 76.9 & 64.1 \\
& Boys & 75.0 & 69.2 & 50.7 & 79.3 & 71.3 & 54.2 \\
\hline \multicolumn{2}{l}{ Total numbers } & $\mathbf{4 6 4 , 1 0 0}$ & $\mathbf{5 3 7 , 5 5 3}$ & $\mathbf{5 6 0 , 1 6 5}$ & $\mathbf{4 9 6 , 0 3 0}$ & $\mathbf{5 1 6 3 9 9}$ & $\mathbf{5 3 6 , 3 9 4}$ \\
\hline
\end{tabular}

Source: National Pupil Database analyses of two longitudinal cohorts

The IDACI decile identifies the area in which the child lives and calculates poverty levels according to the proportion of families in that area in receipt of benefits. The FSM label attaches to the individual and signifies a pupil's entitlement to free school meals at any point in the previous six years, thus comparing a group of about $20 \%$ deemed to be in poverty compared with the remaining $80 \%$. The gender data are discussed later.

At KS 4, KS 2 and KS 1, there is the same relentless increase in the percentage reaching the expected benchmarks with each decile step from poorest to most affluent. The same uninterrupted rise is evident in both datasets three years a part. The gap between top and bottom would appear to grow considerably from KS1, through KS2 to $\mathrm{KS} 4$, an indication of a greater attenuation of the difference between richer and poorer. The FSM-Non-FSM comparison shows this starkly. Poverty matters. Whatever the causal links, low family income affects attainment at every level, every year with both sexes and all ethnic groups. The attainment data for 2017, Table 4, show the FSM nonFSM for 9-5 GCSE passes in English and mathematics (column 4) to be 21.7/45.8 and for achieving all components of the English Baccalaureate (column 5) to be a proportionately greater gap of 8.6/23.3.

\section{Ethnicity and educational attainment}

It is important to set out the numbers and breakdown of ethnicity categories and note changes over time as a foundation for serious analysis of cause and response to educational inequalities related to ethnicity. Table 2 shows the numbers of ethnic minority children in English state schools in 2011 and 2018. Minority Ethnic pupils 
made up $31.8 \%$ of the school population in 2017 , up $7.5 \%$ from 2011 . Pakistanis make up the largest single group, but constitute only a little over $4 \%$. The three Black groups together only account for $5.7 \%$ of the school population. Mixed White and Black Caribbean children have become more numerous in 2018 than those categorised as Black Caribbean - an indicator of mixed race relationships. The biggest numerical increase over this period has been of Black Africans.

Table 2: Numbers and percentages of pupils by ethnicity in schools in England in 2011 and 2018

\begin{tabular}{lrr|rr} 
& \multicolumn{2}{c|}{$\mathbf{2 0 1 1}$} & \multicolumn{2}{c}{$\mathbf{2 0 1 8}$} \\
& Number & \multicolumn{1}{c}{$\%$} & Number & \multicolumn{1}{c}{$\%$} \\
\hline White & $5,252,850$ & 79.1 & $6,017,392$ & 74.0 \\
White British & $4,960,770$ & 74.7 & $5,446,536$ & 67.0 \\
Traveller/Roma & 17,820 & 0.3 & 32,683 & 0.4 \\
\hline Mixed White \& Black Caribbean & 86,325 & 1.3 & 123,387 & 1.5 \\
Mixed White \& Black African & 30,730 & 0.5 & 63,169 & 0.8 \\
Mixed White \& Asian & 59,340 & 0.9 & 111,173 & 1.4 \\
Other Mixed background & 98,385 & 1.5 & 172,847 & 2.1 \\
\hline Indian & 167,250 & 2.5 & 246,161 & 3.0 \\
Pakistani & 242,575 & 3.7 & 356,981 & 4.4 \\
Bangladeshi & 99,730 & 1.5 & 142,104 & 1.7 \\
Other Asian background & 91,395 & 1.4 & 149,815 & 1.8 \\
\hline Black Caribbean & 92,095 & 1.4 & 91,188 & 1.1 \\
Black African & 197,845 & 3.0 & 308,951 & 3.8 \\
Other Black background & 38,630 & 0.6 & 61,569 & 0.8 \\
\hline Other & 117,330 & 1.8 & 189,377 & 2.3 \\
\hline Total Minority Ethnic Pupils & $1,613,690$ & $24.3 \%$ & $2,587,578$ & $31.8 \%$ \\
All pupils & $\mathbf{6 , 6 3 8 , 8 8 5}$ & & $\mathbf{8 , 1 3 2 , 3 2 7}$ & \\
\hline Source: calculat
\end{tabular}

Source: calculated from DfE, 2011, Table 4; DfE, 2018b, Table 4a.

Black, Mixed and Asian groups are disaggregated because they have different experiences and outcomes in a range of public spheres. There is variation from local authority to local authority in the ethnic groups and the relative sizes constituting local populations; some LAs have over 50\% ethnic minority pupils, Manchester, Birmingham and Leicester have over 60\% and Inner London over 80\% (DfE, 2018b, Table 9a). Fine-grained analysis of the ethnic heritages making up the local school 
populations is important to determine action locally to address inequalities. The reasons for this are further apparent in Table 4.

Table 3: Attainment at KS 1, KS 2 and KS 4 by Ethnicity for two longitudinal national cohorts of pupils

\begin{tabular}{llll|lll}
\hline & \multicolumn{3}{l|}{ Cohort reaching 16 in 2012 } & \multicolumn{3}{l}{ Cohort reaching 16 in 2015 } \\
\hline & KS1 & KS2 & KS4 & KS1 & KS2 & KS4 \\
& Level 2 & Level 4 & $\mathbf{5 A *}$ C & Level 2 & Level 4 & 5A*-C \\
& Reading, & Eng, & GCSE inc & Reading, & Eng, & GCSE inc \\
& Writing, & Maths, & Eng \& & Writing, & Maths, & Eng \& \\
& Maths & Science & Maths & Maths & Science & Maths \\
\hline White British & $\mathbf{8 0 . 7 \%}$ & $\mathbf{7 1 . 8 \%}$ & $\mathbf{5 5 . 8 \%}$ & $\mathbf{8 4 . 3 \%}$ & $\mathbf{7 5 . 4 \%}$ & $\mathbf{5 4 . 2 \%}$ \\
Mixed White \& Black Caribbean & $77.0 \%$ & $67.0 \%$ & $47.3 \%$ & $80.8 \%$ & $71.5 \%$ & $45.3 \%$ \\
Mixed White \& Black African & $78.1 \%$ & $68.6 \%$ & $59.4 \% *$ & $82.3 \%$ & $74.1 \%$ & $55.3 \% *$ \\
Indian & $82.6 \% *$ & $76.0 \% *$ & $74.1 \% *$ & $86.2 \% *$ & $80.1 \% *$ & $71.3 \% *$ \\
Pakistani & $69.5 \%$ & $58.9 \%$ & $50.1 \%$ & $75.0 \%$ & $65.2 \%$ & $49.3 \%$ \\
Bangladeshi & $67.1 \%$ & $63.8 \%$ & $58.8 \% *$ & $76.5 \%$ & $70.3 \%$ & $59.8 \% *$ \\
Black Caribbean & $72.0 \%$ & $59.0 \%$ & $46.2 \%$ & $78.0 \%$ & $66.6 \%$ & $42.6 \%$ \\
Black African & $69.8 \%$ & $59.1 \%$ & $56.5 \% *$ & $77.4 \%$ & $67.6 \%$ & $54.1 \%$ \\
Other Black background & $70.9 \%$ & $57.4 \%$ & $48.4 \%$ & $76.2 \%$ & $64.6 \%$ & $44.6 \%$ \\
Traveller/Gypsy/Roma & $41.6 \%$ & $27.5 \%$ & $8.7 \%$ & $54.2 \%$ & $24.5 \%$ & $8.5 \%$ \\
\hline Source: Notion
\end{tabular}

Source: National Pupil Database analyses of two longitudinal cohorts

Table 3 is derived from the from the researcher's NPD datasets and displays the

percentages achieving the benchmark levels as they move through each of the key

stages. Though three years apart, the same groups excel $(*)$, the same groups at the

same key stages have average attainment levels lower than for White British pupils

(shaded cells). Travellers and Roma score lowest across the row. Black Caribbean,

Mixed White \& Black Caribbean, Other Black background and Pakistani pupils fare

relatively poorly at KS 4 while Black African and Bangladeshi pupils have a definite

upward trajectory, particularly from KS 2 to KS 4, to arrive on a par with White

British. Pakistani pupils do not make this progress. 
Table 4: Attainment at GCSE by Ethnicity, First Language and Free School Meals and Gender 2017

\begin{tabular}{|c|c|c|c|c|c|}
\hline Ethnicity & $\begin{array}{l}\text { Number of } \\
\text { pupils at } \\
\text { the end of } \\
\text { key stage } 4\end{array}$ & $\begin{array}{l}\text { Average } \\
\text { Attainment } \\
8 \text { score }\end{array}$ & $\begin{array}{c}\% \text { of pupils } \\
\text { achieving } 9-5 \\
\text { pass in English } \\
\& \text { maths GCSEs }\end{array}$ & $\begin{array}{c}\% \text { of pupils } \\
\text { achieving all } \\
\text { components of } \\
\text { English } \\
\text { Baccalaureate }\end{array}$ & $\begin{array}{l}\text { Average } \\
\text { Progress } \\
8 \text { score }\end{array}$ \\
\hline White British & 378,108 & 45.9 & 42.1 & 20.0 & -0.14 \\
\hline Irish & 1,676 & 51.6 & 55.0 & 32.5 & 0.08 \\
\hline Traveller of Irish heritage & 118 & 23.8 & 9.3 & 3.4 & -1.13 \\
\hline Gypsy / Roma & 1,073 & 18.0 & 4.7 & 1.4 & -0.80 \\
\hline Other White background & 25,367 & 46.5 & 41.4 & 24.5 & 0.49 \\
\hline White \& Black Caribbean & 7,038 & 41.3 & 31.1 & 13.9 & -0.33 \\
\hline White \& Black African & 2,714 & $47.0^{*}$ & 42.8 & 22.7 & 0.08 \\
\hline White \& Asian & 5,147 & $51.8^{*}$ & 53.9 & 30.6 & 0.16 \\
\hline Other mixed background & 8,584 & $48.8^{*}$ & 46.7 & 27.0 & 0.12 \\
\hline Indian & 13,968 & $55.4^{*}$ & 61.9 & 39.2 & 0.69 \\
\hline Pakistani & 21,323 & 45.0 & 38.6 & 19.0 & 0.25 \\
\hline Bangladeshi & 8,874 & $49.9^{*}$ & 48.4 & 25.5 & 0.49 \\
\hline Other Asian background & 8,622 & $52.3 *$ & 57.2 & 34.4 & 0.67 \\
\hline Black Caribbean & 7,097 & 40.5 & 28.7 & 13.0 & -0.23 \\
\hline Black African & 17,466 & $46.9^{*}$ & 43.5 & 23.5 & 0.37 \\
\hline Other Black background & 3,359 & 42.6 & 32.1 & 17.5 & 0.03 \\
\hline Chinese & 2,073 & $62.6^{*}$ & 72.0 & 49.5 & 0.93 \\
\hline Other ethnic group & 8,441 & $46.8^{*}$ & 43.6 & 25.7 & 0.60 \\
\hline \multicolumn{6}{|l|}{ First Language } \\
\hline English & 442,222 & 46.3 & 42.7 & 20.8 & -0.11 \\
\hline Other than English & 83,905 & 46.8 & 42.8 & 24.2 & 0.50 \\
\hline \multicolumn{6}{|l|}{ Free school meals (FSM) } \\
\hline FSM & 69,261 & 35.0 & 21.7 & 8.6 & -0.48 \\
\hline All other pupils & 458,598 & 48.0 & 45.8 & 23.3 & 0.04 \\
\hline \multirow[t]{2}{*}{ Gender } & 259,332 & 49.0 & 47.7 & 25.7 & 0.18 \\
\hline & 268,527 & 43.7 & 39.6 & 17.1 & -0.24 \\
\hline All pupils & 527,859 & 46.3 & 42.6 & 21.3 & -0.03 \\
\hline
\end{tabular}

Source: DfE (2018a) Table CH1

The numbers of pupils assessed at Key Stage 4 (column 2) are an indication of the scale and location of 'problem' areas. The Attainment $8^{3}$ score (column 3 ) is the current key assessment measure. GCSE results analysed by ethnicity show nine minority ethnic groups* with average attainment levels in 2017 which exceed the national and White British average. The 'ethnic penalty', referred to in a government publication over 10 years ago (DCSF, 2007, p.4), no longer applies so simply or to the same 
degree in English education in 2017. Chinese and Indian students have traditionally scored highly. In the period from 2008 to 2017 , the mean proportion achieving 5A*-C GCSE grades for Black African pupils, a group that has increased greatly in number over the period, exceeded that for White pupils. These and Mixed White and Black African, Mixed White and Asian and Bangladeshi children have average Attainment 8 and Progress 8 scores above the national average. As in the previous 15 years (at least), Black Caribbean, Other Black background, Mixed White/Black Caribbean and Pakistani pupils have lower mean attainment levels, with Traveller and Gypsy/Roma pupils having the lowest mean scores (all shaded in column 3, Table 4). These regularities and changes are examined in more detail elsewhere (Parsons, 2016).

It is noteworthy that the percentages achieving grades $9-5$ in both English and maths (column 4) and the components of the EBacc (column 5) show greater inequalities, these being narrower, high status measures.

There are important inequalities related to ethnicity shown in these data but it is important to take the analysis to the level of these subgroups; analysis by the aggregate Black, Mixed or Asian groups is misleading; combining Black Caribbean and Black African is to ignore their different backgrounds and educational outcomes.

Being an English first language speaker or having a language other than English made little difference to attainment. The 69,000 FSM-entitled pupils, $13.1 \%$ of the total, had a very low average Attainment 8 score. This group is more than three times as large as the total of the six low attaining ethnic minority groups.

Race related injustices persist in educational attainment, exacerbated by the changes in assessment content. Equality Impact Assessment, as part of the Public Sector Equality Duty (EHRC, 2016a), should identify the uneven impact such changes have on the 
accredited attainment of specific groups but this quasi-legal mechanism operates weakly, if at all.

The ethnic make-up of the present-day school population in England, and the way it is changing over time, demand that race-based explanations focus on the particulars of ethnicity and the class characteristics of schooling in England.

\section{Gender and educational attainment}

In some respects gender is not a concern in relation to attainment. It is worth noting that the average $10 \%$ gap in levels of achievement of $5 \mathrm{~A}^{*}$-C GCSEs between boys and girls and applies every year with little variation across ethnic groups. The text report of the latest statistics notes the continuity of advantage, stating that, 'As in previous years, girls continue to do better than boys in all headline measures' (DfE, 2018a, p. 34). As Martin makes plain, females can 'win' in education but the fight for equality needs to continue and address particular issues faced by girls and women from sexual violence, employment opportunities to relationship subjugation. She points to "the focus on "the problem of boys" and the associated spectre of girls on top' (Martin, 2018, p. 47) fuelling antagonism and gender polarisation. Within schools, there is work to be done to address stereotypes of quiet, undemanding girl pupils and lack of attention and recognition they receive. Girls doing well in education does not necessarily translate into success and earnings equal to those of boys later; female high earners were outnumbered 14 to 1 in 2013/14, actually worsening from the previous year. In terms of role models in state schools, $74 \%$ of teachers are female, yet only $65 \%$ of head teachers are women. If the percentages were equal, there would over 1,500 more female head teachers. In secondary schools, $62 \%$ are female, but only $36 \%$ of head teachers are women (O,Connor, 2015). This is a small indication of adjustments needed to approach equality. On this broader front, the United Nations Gender 
Inequality Index ${ }^{4}$ shows the UK with a score of .193 doing better than the USA (.262) but not as well as France (.080) or Germany (.046) and, of course, nowhere near the Scandinavians (UNDP, 2013).

\section{Class and deprivation explanations of and responses to low attainment}

Townsend and Gordon (2000) summed up in Breadline Europe 18 years ago that, varied though levels of poverty were in different countries, 'The scale and rapidity of this economic and social development seems to have outstripped the capacities of governments and public to react proportionately' (p. 443). The relationship between poverty and educational success has long been established, but the required application of this knowledge, understanding and political will remain absent in 2018.

Government education policy in England, whichever party has been in power, has repeatedly expressed the commitment to raise the levels of attainment of the poorest children. Amongst the many initiatives implemented are Education Priority Areas (Midwinter, 1970), Excellence in Cities (Kendall et al, 2005), Sure Start (Glass, 1999), pupil premium grant (DfE, 2013).

A number of authors have expressed reservations about the likely effectiveness of these compensatory schemes (Bernstein 1970; Gorard, 2010; Whitty and Anders, 2014). One writer argued 20 years ago, 'the most powerful "educational" policy is arguably one which tackles child poverty' (Robinson, 1997, p.3). More recently, on the same theme, it is claimed, 'we should not expect people to transform their lives if they have not been given the resources to make that possible' (Reay, 2017, p.1970).

At the same time, there has been a welter of publications about school effectiveness and school improvement (Harris, 2002; Chapman et al, 2012) and an unquenchable professional and academic optimism that schools can overcome the disadvantages 
associated with poverty and discrimination. The policy initiatives and expressed political commitment have not led to the enduring, desired results; questions remain, even if brushed aside, about the power of underlying forces which create poverty and accompanying family challenges. Anti-poverty interventions and rhetorical emphases, so far employed in England, have not shown lasting results in Great Britain (Parsons, 2016), nor in the USA (Payne and Ortiz, 2017).

The initiatives, driven hard by government and The National College for Teaching and Leadership, have been too slight, partial and time-limited to have widespread or embedded impact. More importantly, they have ignored evidence arising from an ecological conception of children's social location and development. Crucially, the compensatory education and school improvement/leadership focii have deflected serious attention from the role of poverty. Epidemiological work in health has shown convincingly the factors well-known to be related to poor health (Marmot, 2015). More widely, inequality factors relate to life outcomes such as population health, children's welfare, social mobility, crime and punishment, trust and community (Pickett and Wilkinson, 2009). It is not simply the measure of inequality or the rate of social mobility that matter but the depth of poverty and the additional struggles for families to function well that accompany significant levels of poverty.

The poverty research lobby appears to occupy the high moral ground, but practical policy discussions to alleviate poverty centre on early intervention, social mobility, improving parenting, getting people into work and developing resilience and other personal qualities. As Lister summarises the position, the attention is given to such responsive interventions, 'but little [is] said about changing the patterns of disadvantage which create such unequal starting points' (Lister, 2016, p. 4). 
Wedge and Prosser's dated study 'shows that the adversities of some boys and girls can extend into almost every aspect of their health, their family circumstances and their educational development' (Wedge and Prosser, 1973, p. 9) and then proceeds to list bad housing, low income, big families, one-parent families and those for whom these hardships combine and then specific differences between the disadvantaged and 'ordinary' children including prematurity, lower birth weight, three times the mental health problems and even differences in height at age 11 with $58 \%$ of disadvantaged children being of average or greater height and $82 \%$ of the non-disadvantaged reaching this height.

Feinstein's work showed disadvantaged children being measurably behind at 22 months (Feinstein, 2003) and a later cohort longitudinal study repeats this picture for several ages, adding, by way of explanation, 'Poverty adversely affects parental investment, which in turn has a negative impact upon cognitive development. Thus it is not simply that poverty somehow adversely affect children's cognitive development, but rather low income does not facilitate good parenting investment' (Dickerson \& Popli, 2012, p. 20). Cooper and Stewart, in an update of their 2013 Does Money Affect Children's Outcomes?: A Systematic Review find their earlier conclusions strengthened, with studies which draw on the Investment Model and the Family Stress Model whereby, 'an increase in income is associated with a reduction in food insufficiency .... a shortage of resources prevents families from buying the most basic things their children need to thrive' and reduced 'maternal depression [arising from the] damaging effects of poverty on mothers' mental health, itself an important predictor of child well-being and development' (Cooper \& Stewart, 2017, p.27/28). Addressing disadvantage - essentially low income or ungenerous welfare support - is often described in ways which are optimistic but doomed. Raffo, et. al., in Education 
and Poverty in Affluent Countries helpfully plot macro, meso and micro explanations and interventions. However, the problem with their 'socially critical perspective' is that, particularly at the macro-level, 'it is policy makers who need to address these issues [but] are often viewed as part of the problem' (Raffo et al. 2010, p. 193). Ridge and Wright (2008) point to the 'need to focus "upstream" on the "root causes" of inequality' (p. 313) and note, sadly, 'the enduring legacy of the Poor Laws, including the principle of "less eligibility" and pernicious and persistent assumptions about the "deserving" and "undeserving poor"' (p. 319). These analyses of how to address poverty, inequality and injustice, viewed some years later, look decidedly without leverage, even impotent.

\section{Race Theory explanations of and responses to ethnic educational inequalities}

Critical Race Theory (CRT) is to be applauded for the rejuvenated attention given to racism and race inequality in the UK, edging aside the themes of 'multicultural education', 'anti-racist education' and debate about integration or respect for difference. David Gillborn has been impressive, consistent and tireless in promoting this theoretical position in the UK (Gillborn, 2006a, 2008, 2010a; Gillborn et al, 2017). It has, however, serious shortcomings in terms of explaining and offering responses to racialization and race-related inequalities in England. In the time of the last Labour government and under the auspices of the Department for Children, Schools and Families and Every Child Matters, there were focussed projects and funding for ethnic minority low attainment (DCSF, 2007, 2009). Even these distinct projects had questionable results and have disappeared, for funding and ideological reasons. Translated to the UK from the USA, where CRT began, Ladson-Billings (2009) describes its five key elements as: racism is ordinary, embedded and structured by white supremacy; people of colour are racialized; intersectionality where race 
combines with other factors; the power of 'story telling'; and change occurs when it coincides with whites' interests (interest convergence).

While much of this may apply, the UK context and history in terms of Black, Asian and Minority Ethnic (BAME) groups are distinct from those in the USA, though the past repressive and exploitative role of colonialism in the development of the UK's prosperity and the commonwealth origins of recent immigrants are important parts of the contemporary UK condition. Racism and race related outcomes continue in Great Britain in most areas of public life and the criminal justice system (Lammy, 2017; EHRC, 2016b), employment in many sectors, particularly at senior levels (H M Government, 2017) and in terms of attainment and exclusions in the education system.

The research on Black middle classes (Vincent et al., 2015) is an impressive 'intersectional' study of 62 families testing the hypothesis that middle class occupational positions, earnings and life-style do not overcome the disadvantage of skin colour. The parents claim that teachers expect too little academically from their children and that SEN procedures are problematic. They feel that 'racism is a reality in their lives and they invest a considerable amount of time and energy working out how best to manage and circumvent it' (p. 180). Bourdieu and Passeron's (1990) notions of capital, and of 'misrecognition' and 'inharmonious fit' are used to good effect. Strand, from work on the 15,000 sample LSYP, makes a similar point about minority ethnic children from more affluent families that, 'Black Caribbean, Black African and Bangladeshi boys from high SES homes made less than expected progress [although they had] completed the same or greater amounts of homework as their White British peers and had academic self concept and high educational aspirations' (Strand, 2008, p. 40). 
Warmington writes of the different 'British intellectual space' occupied by CRT in the UK. Legislation and policy attend to crude and overt racism while leaving untouched everyday practices (p.141). Indeed, official anti-discrimination operates at the same time as other explicit policy events cause inequalities and predictably disadvantage the same ethnic and socio-economic groups.

There is, however, little specifically CRT that is applied in either of these major studies. In an earlier paper from the former, the authors report, 'The strain of living in a society where Whiteness is the norm extracts psychological costs' (Vincent et al., 2013, p. 940); adults in deprived areas can voice similar feelings when confronted by 'middleclassness'.

In understanding and addressing inequalities a wider, intersectional and structural, perspective is needed. A recognition of the same injustices affecting others, to a large extent for similar structural reasons, suggests that a very real conspiracy is not just perpetrated against Black minority children.

Using Birmingham data available at the time and reported in many articles, a 'conspiracy' claim is made that the change, in 2000, from Baseline assessment to Foundation Stage Profile (FSP) for the assessment of four/five year-olds was made because Black children were outperforming White children on the Baseline measure (Gillborn and Mirza, 2000, p. 16; Gillborn, 2008, p. 99) and the change reasserted the White superiority. This was not a well-based claim as the Baseline assessment was a poorer tool (Lyndsay \& Lewis, 2003), undoubtedly affecting FSM pupils equally and at subsequent key stages the attainment measures for Black children up to KS 4 were unchanged (Parsons \& Thompson, 2017, p. 589, Figure 9).

The claim that statistical manipulation reduced four under-represented ethnic minority groups to one in Strand's papers on the Longitudinal Study of Young People in 
England (LSYPE) data (Strand, 2008) was similarly misguided. Four groups were under-represented in the higher tiers of GCSE courses, but entering prior attainment at 11 into a multivariate statistical model accounted for the lower representation of three of the groups. Gillborn argues, in a fictional discussion between a doctoral student and his professor, that, "just one race inequality survived the statistical manipulations: Black Caribbean pupils' (Gillborn, 2010b, p. 263). However, Strand's analysis is sound and represents intersectionality correctly applied.

The changed 'standard' at 16 , from $5 \mathrm{~A}^{*}$-C GCSEs to the EBacc, was given as another act of conspiracy against ethnic minorities (Gillborn, 2013). Published results by ethnicity, FSM and gender set out in Table 4 show the wide variation across ethnicities. Hardest hit, however, are those eligible for FSM, larger numbers than any ethnic group. The Black/White gap is directly affected, often in negative ways, by changes in education policy. The 'conspiracy' is not targeted at one, or even three, ethnic groups, but at those socially and economically marginalised from mainstream. The curriculum at one school in extremely challenging circumstances, the Marlowe Academy in Ramsgate, Kent, was designed from its inception in 2005 to give progression routes from 14-19 attuned to the benchmark attainment measure at that time, heavily based on vocational courses, where as many as four GCSE equivalents could be achieved via BTEC courses and when maths and English were not a necessary part of the $5 \mathrm{~A}_{-} \mathrm{C}$ criterion. Year after year results improved, until in 2009, the Marlowe Academy was within 4\% of the national average of $68 \%$ (Parsons, 2012, p. 100). The Labour Secretary of State for Education announced the new GCSE floor targets for schools as $30 \%$ of pupils gaining $5 \mathrm{~A}_{-} \mathrm{C}$ grades including maths and English in June 2010 and restricted the contribution that BTEC (vocational) courses 
could make. This plunged the school to near the bottom of the league tables and status protection and class-related differentiation were re-established.

In the way currently construed and applied to the social/racial problems experienced in England, CRT is conceptually self-limiting and shows at times what Delgado and Stefancic refer to as a 'nonchalance about objective truth' (2012, p. 104).

Gillborn's 'It's not a conspiracy, it's worse than that' (Gillborn, 2008) and White Supremacy (Gillborn, 2005, 2006a) are general terms and avoid the difficulties in disentangling the factors associated with unequal outcomes in education and structural, causal analysis and does not acknowledge economic disadvantage, the strongest factor correlating with low educational attainment.

\section{Race and Class - misplaced antagonisms and missed opportunities for alliance}

This section looks for common ground between race and class theorists in explaining inequalities in educational attainment and identifies the shared sources, and sustainers, of injustices in this area. At one level, it is important to continue to monitor attainment levels, exclusions, participation in gifted and talented programmes, access to the higher tier examination options, access to the English Baccalaureate (EBacc) and entry to university by pupil characteristics. Attention should also be paid to apprenticeship uptake by ethnicity and disproportionality in NEETs (not in employment, education or training). The Public Service Equality Duty (PSED) (H M Government, 2010) should operate here, where policies are checked to see if they adversely affect any of the 'protected groups'. With the unifying of the equalities legislation and the demise of the Race Impact Assessment, we need constantly updated knowledge of where inequalities occur and the effectiveness of corrective action. However, monitoring, followed by critical statements and expressions of corrective intent are insufficient, play at the 
wrong level and will not result in significant change if the underlying causes are not correctly identified and then radically rearranged.

A broader approach to the correlates of disadvantage is suggested by Archer and Francis who emphasise, 'the utility and importance of addressing race/ethnicity, gender and social class as integrally related issues that need to be collectively theorised if we are to understand pupils' identities and achievement in schools ... not just at a theoretical or conceptual level, but also in social terms, as a prerequisite for social justice approaches to educational policy and practice' (2007, p. 25). Crozier, similarly has argued for a balance avoiding 'hierarchies of oppression ... social class versus race ... an either or approach, playing off one against the other and not privilege[ing] one form of injustice over another' (2014, p. ix).

The complexity needs to be acknowledged: some immigrant groups have prospered in a wide range of aspects of life while others have not, experiencing inequalities in education, health and criminal justice as well as employment and earnings. We can identify those minorities for whom experience in the UK has worked less well as Irish Travellers, Roma, Black Caribbean and Mixed White/Black Caribbean, and, to a lesser degree, Pakistani. It is important to particularise in this way to acknowledge the variations. Additionally, it is unhelpful to talk of 'model minorities' or to belittle the white working class as the 'new race victims' (Gillborn, 2014, p. 33). Equally, the competitive 'race trumps class' (Hill, 2009, p. 2) language is hardly worthy as an analytical description and is a quasi-intellectual squabble at the wrong level. Both Gillborn and Hill are responding to press interpretations of their contrasting positions. Working towards an alliance, where they address the same sources of injustice, is compromised where effort is diverted into challenging caricatured representations of their position. 
There is something fundamentally conservative about CRT (Darder and Torres, 2004, p. 103), a description shared by much poverty/education research where, for instance, Raffo et al label the volume of meso-level intervention as, at best, 'ameliorative' (Raffo et al. 2010, p. 193) and Ainscow's statement that equitable developments in education depend on government pro-equity policy frameworks, but, 'In the meantime ... much can be achieved by school change' (Ainscow et al, 2010, p. 2). In fact, judging from available evidence over a long period, despite heroic efforts and significant examples, government policy and reallocation of resources is fundamental and the admission that something short of this will 'ameliorate' or that 'much can be achieved' blunts that core argument.

Intersectionality promises much and Collins and Bilge draw attention both to the components of intersectional identities we all have - race, class, gender, sexuality, disability, ethnicity, nation, religion, age - but also to the 'interconnected domains of power: interpersonal, disciplinary, cultural and structural' (Collins and Bilge, 2016, p. 7). They propose that attention be paid to all these 'in relation to educational experiences and outcomes of disenfranchised populations' (p.39). Single issue research has obvious appeal, but will be restrained in theoretical and policy advances. Analysis of educational performance generally shows that the crude ranking of power amongst major factors is deprivation, then gender and then ethnicity ${ }^{5}$. Parsons and Thompson (2017) calculated an overall mean for standardised attainment data (ie producing a mean of zero and a standard deviation of one) for each of the five key stage assessments (Baseline/Foundation Stage Profile to KS4) for 12,000 pupils in each of four cohorts of Birmingham pupils. The overall adjusted means indicated the greater advantage stemming from being a non-FSM pupil (0.493), compared with the advantage of being female (0.195), or being White (0.186) (p. 13). Strand's analysis of 
the performance of 11 year olds gives a similar ordering influences with a low/high SES difference of 0.57 , a Black Caribbean gap of 0.45 and a gender gap of 0.08 (Strand, 2014b, p. 227). Describing this situation, as many have, is not enough and the ranking of discrimination factors is also not to disregard the role of racism revealed in statistics, in qualitative studies and in personal reports. Nor does it detract from the unique ways in which ethnicity, particularly skin colour, can constitute additional barriers.

Sharp and Green (1975) described provocatively forty years ago the labelling of working class families and children in one urban primary school, which did not bode well for their future success in education. McCulloch (1998) asserts that ordinary children have been failed, 'by the contradictions of class based provision and the illusions to which it gave rise' (p. 159). He anticipated new ways would be devised to fail the ordinary child. In the 20 years since his book appeared, including 12 years of a labour government, this has proved to be true. Indeed, Reay makes a similar contemporary point, that, despite multiple policy changes, 'the English educational system is still one that educates individuals according to their class background. It remains a segregated system ... different social classes are largely educated apart' (Raey, 2017, p. 175).

CRT is claimed to be 'a theory of civil rights [and] if racial oppression has material and cultural roots, attacking only its ideational or linguistic expression [microaggressions, racial insults, unconscious discrimination] is apt to do little for the underlying structures of inequality, much less the plight of the deeply poor' (Delgado and Stefancic, 2012, p. 107), and will seem increasingly irrelevant. They draw attention to the disparities in wealth and income between those at the top and bottom, recalling that, 'redistributive measures, progressive tax and a welfare safety net used to 
operate but that such measures excite less support than formerly, concluding that White or Black, 'society tolerates poverty and blighted prospects for outsider groups' (Delgado and Stefancic, 2012, p. 123), lamenting that 'a general theory of race and economics remains elusive' (p. 124), regrettably true of the UK as well as the USA. The concept of racialization has unifying potential across researchers seeking to promote equality. Its importance is in denoting the means by which people are described and marginalised, have demeaning characteristics attributed to them which, when absorbed and insufficiently challenged, give permission to give inferior treatment and close off opportunities. Miles (1989) applies this notion in such a way that it is a dynamic, relational process by which dominance and subservience are ascribed. Some would link this, in part and in some places, to a colonial past (Cole, 2018, p.105; Gupta et. al, 2018). Others would seek the motive forces in the distribution of power to define and the competition for resources, whether in jobs, housing or other credits for social and economic advancement. Both of these can be quite localised depending on competition and the local ethnicities. In schools, the racialization has resulted in 'lively' (and poor) African Caribbean pupils to be labelled 'trouble' and of lesser intelligence; poorer grades, higher rates of school exclusion are a consequence. The growth of and legitimisation of such judgements can be seen as, at a minimum, 'allowed' by elites and law, and reinforced 'on the ground' by a destabilised and exploited working class who see themselves 'sharing' scarce resources.

Finding ways to interrupt the assigning of and withholding of privilege, and understanding the institutional means by which human rights are unequally distributed are tasks of social researchers and policy-makers. To explain working class racism, Miles puts it within a social, economic and hierarchical conceptualisation and urges that: 'to the extent that racism is an attempt to understand a specific combination of 
economic and political relations, and is therefore grounded in those relations, strategies for eliminating racism should concentrate less on trying to persuade those who articulate racism that they are 'wrong' and more on changing those particular economic and social relations' Miles, 1989, p.82).

A structuralist perspective is realistic and important. It focuses attention on the distribution of power in society, inequalities of wealth and income and the creation and maintenance of poor communities. Where there is political will (and it was explicit if not strong in the period to 2010) positive action targeted at key points in school careers is likely to have some equalising effect. Connell asks why market reforms persistently increase inequality to which her reply is: 'They are intended to ... not an accidental side-effect' (Connell, 2013, p. 279). She argues that education could never be protected from the political dynamics of neo-liberalism and its project to restore privilege to elites.

Cole $(2009,2017)$ and Hill (2009) have engaged with the CRT thesis from a Marxist perspective and emphasised the primacy of class. These authors and others press for policies which work upstream from education and concentrate attention on wealth and earnings, control and repression. They also see barriers to the advancement of disadvantaged groups as erected, sustained and reinforced by economic and ideological forces which are protective of establishment interests and elite social groups. Hylton's (2011) Atlantic Crossings, an English collation of 13 articles, includes engagements with Marxism but does not resolve the tensions between CRT's cultural and psychological explanations and Marxism's materialism and does not 'anglicise' CRT. Those foregrounding race or class must acknowledge the forces that stem from controls of finance and labour, the protective class strategies and the advantage to elites where low socio-economic groups (are encouraged to) blame immigrants for 
unemployment and low wages. Maisuria (2012) makes the telling criticism that, 'if CRT cannot connect the subjective micro with the objective macro, with capitalist modes of production and the subjugation that is experienced according to the individuals' and groups' location in the occupational, earnings and wealth hierarchy and, if it can't make the correspondence between structures and agents, then it postulates the futility of resistance against the racist structure of society' (p. 87). Cole writes similarly that CRT, 'in signifying "the enemy" as "white supremacy" (defined very broadly) or "white powerholders" ... fails to make connections to the capitalist economy ... offers no vision of the future, no solution' (Cole, 2017, p. 180).

Writers from a 'left-of-centre' position acknowledge 'race', but see this attribute to be subservient to, or operating within, wider economic and related cultural forces. Certainly, there is a gulf between these thinkers and CRT writers. Writers in the UK on this wider front are similarly in evidence, similarly impotent and largely disregarding race as a prime attribute (Dorling, 2015; Jones, 2011; Smythe \& Wrigley, 2013).

Robinson (1997) and Lister (2016) indicate starkly, unequivocally, that child (meaning family) poverty must be addressed. It is not simple, as the state of affairs where the UK's neo-liberal management of welfare has moved closer to the American model than any of our European neighbours and as Dorling and Tomlinson challenge, 'a major task of the sociology of education has been to demonstrate the ways in which inequalities in education and life chances - particularly by social class, race, gender and disability are sustained and recreated by structures, policies and policy-makers' (Dorling and Tomlinson, 2016, p. 57). Inequalities have interpersonal, disciplinary, cultural and structural dimensions, as Collins and Bilge (2016) articulate, but unless analyses reach to the structural, they will be merely ameliorative, keeping the 'problem' within publicly acceptable bounds, continuing the tradition of 'interventions' to address 
injustices alongside posturing policies which have deliberately produced them. Analyses at too low a level will further allow credibility to the Race Disparity Audit Foreword's banal and disingenuous statement that, 'how far you go in life should be based on your talent and how hard you work - and nothing else'. (H M Government, 2017, p. 1). Centres of power and privilege have powerful hegemonic reinforcement and in seeking remedies relating to social structure and inequities of wealth/power distribution, intellectual reconciliation amongst race, class and gender theorists should be sought in mounting 'counter-hegemonic ... practices [and] politics of interruption of dominant structures, processes and understandings' (Apple 2015, p. 175).

\section{Conclusion}

Researchers in areas of poverty, ethnicity and gender in education have done much to raise the profile of educational inequalities in the UK, but some assertions applied to the English school situation require scrutiny. There is 'conspiracy', but it oppresses several groups simultaneously, groups characterised by their disenfranchised and marginalised status. Girls in school out-perform boys, but the extent of this varies slightly by ethnicity and deprivation levels. Claims of a 'conspiracy' which adversely affects one specific ethnic group, Black pupils, or a sub-set of Black Caribbean pupils, may have popular appeal. It is, however, misleading, a diversion from the character of broader social injustice and an over-statement and misuse of data which can damage what might otherwise be a good case. The disregard for the larger numbers, identified by factors other than race, suffering unequal treatment and diminished life chances is perverse. 'Intersectionality', to have useful meaning must acknowledge the full range of correlates of poor educational outcomes, chief amongst them poverty, and the common forces and groupings behind decisions about education which preserve class advantage. It is important to grasp the weighting of correlates of unequal outcomes in 
education, and to recognise the particular features of experienced inequality. The further need is in theorising and explaining to uncover why the inequalities are made, how they are sustained, which groups benefit from the manufactured injustices and how the situation is rendered normal, acceptable and inevitable.

\section{Acknowledgements}

My thanks are due to a number of friends and colleagues who have commented on earlier drafts: David Ewens, Gill Fairbanks, Ray Godfrey, Amanda Henshall, George Hudson and Stephen Steadman.

\section{References}

Ainscow, M., Dyson, A., Goldick, S. \& West, M. (2010). Developing Equitable Education Systems. London: Routledge.

Apple, M. W. (2015). Understanding and interrupting hegemonic projects in education: learning from Stuart Hall. Discourse: studies in the cultural politics of education, $36,171-184$.

Archer, L. \& Francis, B. (2007). Understanding Minority Ethnic Achievement: race, gender, class and 'success'. London: Routledge.

Bernstein, B. (1970). Education cannot compensate for society, New Society, 26 February, 344-47.

Bourdieu, P \& Passeron, J. (1990). Reproduction in Education, Society and Culture, London: Sage.

Chapman, C., Armstrong, P., Harris, A., Muijs, D., Reynolds, D. \& Sammons, P. (2012). School Effectiveness and Improvement Research, Policy and Practice: Challenging the Orthodoxy? London: Routledge.

Christensen, J. (2009). Basic Income, Social Justice and Freedom. York: JRF. https://www.jrf.org.uk/report/basic-income-social-justice-and-freedom

Cole, M. (2009). Critical Race Theory and Education: A Marxist Response. Basingstoke: Palgrave MacMillan.

Cole, M. (2017). New Developments in Critical Race Theory and Education. London: Palgrave MacMillan.

Cole, M. (2018). Racism and education: from Empire to May. In: M. Cole Education, Equality and Human Rights. London: Routledge.

Collins, P. H. \& Bilge, S. (2016). Intersectionality. Cambridge: Polity Press.

Connell, R. (2013) Why do market 'reforms' persistently increase inequality? Discourse: Studies in the Cultural Politics of Education, 34, 279-285. 
Cooper, K. \& Stewart, K. (2017). Does money affect children's outcomes? an update. London: Centre for Analysis of Social Exclusion - London School of Economics.

Crozier, G. (2014). Foreword. In: R. Race \& V. Lander, Advancing Race, and Ethnicity in Education, Houndsmills: Palgrave Macmillan.

Darder, A. \& Torres, R. D. (2004). After Race: racism after multiculturalism, New York, NY: New York University Press.

DCSF (2007) Ensuring the Attainment of Black Pupils (The National Strategies: Secondary). Nottingham, DCSF Publications.

DCSF (2009). Black Children's Achievement Programme Evaluation. London: Department for Children, Schools and Families.

Delgado, R. \& Stefancic, J. (2012). (2 ${ }^{\text {nd }}$ edition). Critical Race Theory: An Introduction. New York, NY: New York University Press.

DfE (2011). Schools, pupils and their characteristics: January 2011. London: Department for Education. Retrieved from https://www.gov.uk/government/statistics/schools-pupils-and-their-characteristicsjanuary-2011

DfE (2013). Pupil Premium Funding, London: Department for Education

DfE (2015). The National Pupil Database: User Guide. London: Department for Education.

https://assets.publishing.service.gov.uk/government/uploads/system/uploads/attach ment_data/file/472700/NPD_user_guide.pdf

DfE (2018a). Revised GCSE and equivalent results in England: 2016 to 2017. London: Department for Education. Retrieved from https://www.gov.uk/government/statistics/revised-gcse-and-equivalent-results-inengland-2016-to-2017

DfE (2018b). Schools, pupils and their characteristics: January 2018. London: Department for Education. Retrieved from https://www.gov.uk/government/statistics/schools-pupils-and-their-characteristicsjanuary-2018

Dickerson, A. \& Popli, G. (2012). Persistent poverty and children's cognitive development: Evidence from the UK Millennium Cohort Study, London: Institute of Education - Centre for Longitudinal Studies.

Dorling, D. (2015). Injustice: why social inequality persists. Bristol: Policy Press.

Dorling, D. \& Tomlinson, S. (2016). The creation of inequality: myths of potential and ability, Journal of Critical Education Policy, 14, 56-79.

EHRC (2016a). Equality Impact Assessments, London: Equality and Human Rights Commission. https://www.equalityhumanrights.com/en/advice-andguidance/equality-impact-assessments

EHRC (2016b). Healing a Divided Britain: the need for a comprehensive race equality strategy. London: Equality and Human Rights Commission. https://www.equalityhumanrights.com/sites/default/files/healing_a_divided_britai $\mathrm{n}$ - the need for a comprehensive race equality strategy final.pdf

Feinstein, L. (2003) Inequality in the Early Cognitive Development of British Children 
in the 1970 Cohort, Economica, 70, 73-97.

Gillborn, D. (2005). Education policy as an act of White supremacy: Whiteness, critical race theory and education reform. Journal of Education Policy, 20, 485505.

Gillborn, D. (2006a). Citizenship education as Placebo: 'Standards', institutional Racism and Educational Policy. Education, Citizenship and Social Justice, 1, 83104.

Gillborn, D. (2006b). Critical Race Theory and Education: racism and anti-racism in educational theory and praxis. Discourse: Studies in the Cultural Politics of Education, 27, 11-32.

Gillborn, D. (2008). Racism and Education: Coincidence or Conspiracy. London: Routledge.

Gillborn, D. (2010a). The White Working Class, Racism and Respectability: Victims, Degenerates and Interest-Convergence. British Journal of Educational, Studies, $58,2: 25$.

Gillborn, D. (2010b). The colour of numbers: surveys, statistics and deficit-thinking about race and class. Journal of Education Policy, 25, 253-276.

Gillborn, D. (2013). Interest-divergence and the colour of cutbacks: race, recession and the undeclared war on Black children. Discourse: Studies in the Cultural Politics of Education, 34, 477-491.

Gillborn, D. (2014). Racism as Policy: A Critical Race Analysis of Education Reforms in the United States and England. The Educational Forum, 78, 26-41.

Gillborn, D. (2015). Intersectionality, Critical Race Theory, and the Primacy of Racism: Race, Class, Gender, and Disability in Education. Qualitative Inquiry, 21, 277-287.

Gillborn, D., Demack, S., Rollock, N. \& Warmington, P. (2017). Moving the goalposts: Education policy and 25 years of the Black/White achievement gap British Educational Research Journal. 43, 848-874.

Gillborn, D. \& Mirza, H. S. (2000). Educational Inequality: Mapping Race, Class and Gender - a Synthesis of Research Evidence. London: OFSTED.

Glass, N. (1999) Sure Start: The Development of an Early Intervention Programme for Young Children in the United Kingdom. Children \& Society, 13, 257-264.

Gorard, S. (2010). Education can compensate for society - a bit. British Journal of Educational Studies, 58, 47-65.

Gupta, T. D., James, C. E., Anderson, C., Galabuzi, G-E., \& Maaka, R. C. A. (2018). Race and Racialization. Toronto: Canadian Scholars

Harris, A. (2002) School Improvement: What's In It For Schools? London: Routledge.

Hill, D. (2009). Race and Class in Britain: a critique of the statistical basis for Critical Race Theory in Britain: and some political implications. Journal for Critical Education Policy Studies, 7, 1-40.

H M Government (2010). Equality Act 2010. London: The Stationery Office.

H M Government (2017). Race Disparity Audit. London: Cabinet Office. 
https://www.gov.uk/government/uploads/system/uploads/attachment_data/file/650 723/RDAweb.pdf

Hylton, K., Pilkington, A., Warmington, P. and Housee, S. (eds) (2011). Atlantic Crossings: International Dialogues on Critical Race Theory. Monograph No. 15. Birmingham: University of Birmingham.

Jones, O. (2011). Chavs: The Demonization of the Working Class. London: Verso.

Kendall, L., O’Donnell, L., Golden, S., RidleyK., Machin, S., Rutt, S., McNally, S., Schagen, I., Meghir, C., Stoney, S., Morris, M., West, A and Philip Noden (2005). Excellence in Cities: The National Evaluation of a Policy to Raise Standards in Urban Schools 2000-2003, Slough: NFER.

http://webarchive.nationalarchives.gov.uk/20130323031127/https://www.educatio n.gov.uk/publications/eOrderingDownload/RR675A.pdf

Ladson-Billings, G. (2009). Just what is critical race theory and what's it doing in a nice field like education? In: E. Taylor, D. Gillborn and G. Ladson-Billings (Eds) Foundations of critical race theory. London: Routledge.

Lammy, D. (2017). The Lammy Review: An independent review into the treatment of, and outcomes for, Black, Asian and Minority Ethnic individuals in the Criminal Justice System, London: HMG.

https://www.gov.uk/government/publications/lammy-review-final-report

Lister, R. (2016). What do we mean by life chances? In: J. Tucker (Ed) Improving Children's Life Chances. London: CPAG.

Lyndsay, G. \& Lewis, A. (2003). An Evaluation of the Use of Accredited Baseline Assessment Schemes in England. British Educational Research Journal, 29, 149167.

Maisuria, A. (2012). A critical appraisal of critical race theory (CRT): limitations and opportunities. In: K. Bhopal \& J. Preston (Eds) Intersectionality and "Race" in Education. London: Routledge.

Marmot, M. (2015). The Health Gap: The Challenge of an Unequal World, London: Bloomsbury.

Martin, J. (2018). Gender and education: perspectives through time. In: Cole, M. Education, Equality and Human Rights: Issues of Gender, 'Race' Sexuality, Disability and Social Class. Abingdon: Routledge.

McCulloch, G. (1998). Failing the Ordinary Child? The theory and practice of working-class education. Buckingham: Open University Press.

Midwinter, E. (1970). Curriculum and the E.P.A. community school. Liverpool: Liverpool Educational Priority Area Project.

Miles, R. (1989). Racism. Milton Keynes: Open University.

O'Connor, L. (2015). Where are all the female headteachers? Guardian, 11.02.2015 https://www.theguardian.com/women-in-leadership/2015/feb/11/lack-of-femaleheadteachers-gender-diversity-education.

Parsons, C. (2012). Schooling the Estate Kids. Rotterdam: Sense Publishers. 
Parsons, C. 2016). Ethnicity, gender, deprivation and low educational attainment in England - political arithmetic, ideological stances and the deficient society. Education, Citizenship and Social Justice, 11, 160-183.

Parsons, C. \& Thompson, T. (2017). Ethnicity, disadvantage and other variables in the analysis of Birmingham longitudinal school attainment datasets. Educational Review, 69, 577-599.

Payne, C. M. and Ortiz, C. M. (2017). Doing the impossible: The limits of schooling, the power of poverty. Annals of the American Academy of Political and Social Science, 673, 32-59.

Pickett, K. and Wilkinson, R. (2009). The Spirit Level: Why More Equal Societies Almost Always Do Better. London: Allen Lane,

Raffo, C., Dyson, A., Gunter, H., Hall, D., Jones, L. \& Kalambouka, A. (2010). Poverty and Educational Policy Initiatives: a Review. In: Raffo, C. et al. Education and Poverty in Affluent Countries. London: Routledge.

Reay, D. (2017). Miseducation: inequality, education and the working classes. Bristol: Policy Press.

Ridge, T. and Wright, S. (2008). Conclusions. In: Understanding Inequality, Poverty and Wealth. Bristol: Policy Press.

Robinson, P. (1997). Literacy, Numeracy and Economic Performance. London: LSE Centre for Economic Performance.

Sharp, R. \& Green A. (1975). Education and social control: a study in progressive primary education. London: Routledge and Kegan Paul.

Smythe, J. \& Wrigley, T. (2013). Living on the Edge: Rethinking Poverty, Class and Schooling. New York: Peter Lang Publishing.

Strand, S. (2008). Minority ethnic pupils in the Longitudinal Study of Young People in England: Extension report on performance in public examinations at age 16. Research Report, DCSF-RR029. London: DCSF.

Strand, S. (2011). The limits of social class in explaining ethnic gaps in educational attainment. British Educational Research Journal, 37, 197-229.

Strand, S. (2014a). Ethnicity, gender, social class and achievement gaps at age 16: intersectionality and 'getting it' for the white working class. Research Papers in Education, 29, 131-171.

Strand, S. (2014b). School effects and ethnic, gender and socio-economic gaps in educational achievement at age 11, Oxford Review of Education, 40, 223-245.

Tomlinson, S. (2001). Education in a post-welfare society. Buckingham: Open University Press.

Townsend, P. \& Gordon, D. (2000). Conclusion, In Breadline Europe: The Measurement of Poverty. Bristol: The Policy Press.

Tucker, J. (2016). Improving Children's Life Chances. London: CPAG.

UNDP (2013). Gender Inequality Index. New York: United Nations Development Programme. http://hdr.undp.org/en/content/gender-inequality-index

Vincent, C., Ball, S., Rollock, N. \& Gillborn, D. (2013). Three generations of racism: 
Black middle-class children and schooling. British Journal of Sociology of Education, 34, 929-946.

Vincent, C., Rollock, N., Ball, S. \& Gillborn, D. (2015). The Colour of Class: The Educational Strategies of the Black Middle Classes. London: Routledge.

Warmington, P. (2014). Black British Intellectuals and Education. London: Routledge.

Wedge, P. \& Prosser, H. (1973). Born to Fail. London: Arrow Books in association with the National Children's Bureau.

Whitty, G. \& Anders, J. (2014). (How) did New Labour narrow the achievement and participation gap? London: Institute of Education, Centre for Learning and Life Chances in Knowledge Economies and Societies.

Woods, D. \& Brighouse, T. (2013). The A-Z of School Improvement: Principles and Practice. London: Bloomsbury Education.

\footnotetext{
${ }^{1}$ The process of applying for data from the National Pupil Database is arduous, in identifying the variables of interest and specifying these in the terms in which they are held and in satisfying the DfE of the robustness and high level conformity of the institution's data protection procedures. The database is a repository of complete cohorts of pupils in schools in England and allows multiple analyses.

${ }^{2}$ Data could be missing because the children were not at school in England at these earlier assessment points.

${ }^{3}$ Attainment 8 is students' average achievement across 8 subjects: English, mathematics, three other English Baccalaureate subjects and three other subjects. Progress 8 is a calculation of progress from the measured attainment at key stage 2; 0 indicates satisfactory progress with negative and positive numbers expressing better or worse progress.

${ }^{4}$ The Gender Inequality Index gives a score from 0 to 1 , the lower the more gender equal. The GII has three dimensions: reproductive health, empowerment and labour market participation. The dimensions are captured in one synthetic index, as to account for joint significance. The UNDP claims that none of the measures pertains to the country's development and a less-developed country can perform on this measure for which the dimensions are considered to be complementary in that inequality in one tends to affect inequality in another.
}

${ }^{5}$ The different powers of the major factors are presented in different ways from 'odds ratios', to 'gaps' to multiple regression calculations. The answers, in common-sencse terms are much the same in the ranking of factors. 